\title{
Nurmisäilörehukokeita maatilasiiloissa 2. Kivennäispitoisuuden muutokset ja säilöntätappiot
}

\author{
Majua-Lissa Salo ja Rittta Sormunen \\ Helsingin yliopiston kotieläintieteen laitos, 00710 Helsinki \\ Investigations of grass silage prepared in ordinary farm conditions \\ 2. Changes in mineral composition and mineral losses
}

\author{
Maija-Liisa Salo and Rirtta Sormunen \\ Department of Animal Husbandry, University of Helsinki, 00710 Helsinki
}

\begin{abstract}
Changes in the mineral composition and the mineral losses of grass ensiled in ordinary farm conditions were investigated on the Viik Experimental Farm in the years $1970-1973$. The grass was ensiled in 9-m-high concrete silos, and layers of wilted and fresh or rain-soaked wilted grass were often put in the same silo. The investigation was made with the aid of experimental sacks. The material was the same as in part 1. The minerals were determined on 45 grass samples and 79 samples of corresponding silages, 61 made from wilted grass (some rain-soaked) and 18 from fresh.

The $\mathrm{P}$ and $\mathrm{K}$ contents of the grass decreased $(\mathrm{P}<0.001)$ and the $\mathrm{Mg}$ and $\mathrm{Ca}$ contents increased $(\mathrm{P}<0.05-0.01)$ from the first to the third cutting. Similar differences were seen in the silages.

The preservation losses of $\mathrm{Ca}, \mathrm{Mg}, \mathrm{K}, \mathrm{P}$ and $\mathrm{Cl}$ were smaller when the grass had been wilted $(\mathrm{P}<0.001)$. The highest loss was observed in samples which were exposed to a strong flow of effluent from above. Rain during harvest was another cause of heavy losses.

Since the losses of ash were about $1 / 3$ higher than those of DM, the mineral contents were $0-10 \%$ lower in silage than in grass. The decrease in the contents of most macrominerals was significantly smaller when the grass had been wilted $(\mathrm{P}<0.001)$. The contents of $\mathrm{Mn}, \mathrm{Zn}$ and $\mathrm{Cu}$ varied rather widely, but, on average, they were only slightly lower in silage than in grass. The presence of soil greatly increased the content of Fe.

High correlations were observed between the following pairs of minerals: $\mathrm{Ca} / \mathrm{Mg}$, $\mathrm{P} / \mathrm{K}, \mathrm{K} / \mathrm{Cl}, \mathrm{Fe} / \mathrm{Na}$, and $\mathrm{Fe} / \mathrm{Zn}(\mathrm{P}<0.001)$, and also between some organic components and minerals. The dependence of mineral losses on the moisture content of the grass was clearest in the samples harvested in rain and in those ensiled in the upper third of the silos
\end{abstract}

\section{Johdanto}

Säilörehun kivennäiskoostumus riippuu pääasiassa raaka-aineen koostumuksesta, mutta pienessä määrin siihen vaikuttaa myös puristemehussa huuhtoutuneiden kivennäisten määrä. Mitä enemmän puristemehua muodostuu, sitä suuremmat ovat tappiot ja rehun kivennäispitoisuuden lasku (WATson 
ja NAsH 1960). Naatteja säilöttäessä puristemehun merkitys tulee selvästi esille (SALO ym. 1974). Kotieläinhoidon tutkimuslaitoksen säilörehututkimuksissa on selvitelty niittotuorena säilötyn nurmirehun kivennäispitoisuuksia ja -tappioita (Poutiainen ja Rinne 1971, Kossila ym. 1973). Tässä tutkimuksessa pyrittiin selvittelemään säilörehun kivennäiskoostumusta ja -tappioita käytännön oloissa, missä ruohoa esikuivattiin pellolla aina kun sää sen salli ja rehu tehtiin korkeisiin tornisiiloihin, jotka täytettiin yksi kerrallaan. Samoihin siiloihin tuli usein sekä esikuivattua että märkää ruohoa. Kolmannen korjuukerran ruoho pantiin useimmiten entisen rehun päälle.

\section{Kokeiden suoritus}

Aineisto oli sama kuin tutkimuksen osassa 1. Kivennäismääritykset tehtiin 45 ruoho- ja 79 vastaavasta säilörehunäytteestä, joista esikuivattuja oli 61 (osa sateen kastelemia) ja niittotuoreita 18. Kationit määritettiin AA-Techtron atomiabsorptiospektrofotometrillä, kloori hopeanitraattititrauksella ja fosfori TAUSSKY ja SHORRin (1953) mentelmällä. Tulosten tilastollinen käsittely suoritettiin Helsingin yliopiston laskentakeskuksessa.

\section{Tulokset}

\section{Ruohon ja vastaavan säilörehun kivennäiskoostumus}

K orju u k r rat. Säilörehun raka-aineen kivennäiskoostumus korjuukerroittain esitetään taulukossa 1 ja vastaavien säilörehujen taulukossa 2 . Kalsiumin, magnesiumin ja mangaanin pitoisuudet nousivat pienessä määrin syksyä kohti, fosfori- ja kaliumpitoisuudet alenivat, viimeksimainitut erittäin merkitsevästi. Korkea kalsiumpitoisuus kolmannen korjuukauden rehussa johtunee osaksi siitä, että mukana oli apilapitoista niittonurmen odelmaa. Vastaavissa säilörehuissa todettiin samat muutokset. Pitoisuudet olivat ruo-

Taulukko 1. Ruohon kivennäiskoostumus 1., 2. ja 3. korjuukertana.

Table 1. Mineral composition of grass of 1st, 2nd and 3rd cuttings.

\begin{tabular}{|c|c|c|c|c|c|c|c|c|c|c|}
\hline & \multirow{2}{*}{\multicolumn{2}{|c|}{$\begin{array}{c}1 \\
\left(n^{=}=21\right) \\
\end{array}$}} & \multirow{2}{*}{\multicolumn{2}{|c|}{$\begin{array}{c}2 \\
(\mathrm{n}=11) \\
\end{array}$}} & \multirow{2}{*}{\multicolumn{2}{|c|}{$\begin{array}{c}3 \\
(n=13) \\
\end{array}$}} & \multicolumn{4}{|c|}{ Merkitsevyys - Significance $^{1}$ ) } \\
\hline & & & & & & & \multirow[b]{2}{*}{ NS } & \multirow[b]{2}{*}{.05} & \multirow[b]{2}{*}{.01} & \multirow[b]{2}{*}{.001} \\
\hline & $\overline{\bar{x}}$ & $\mathrm{~S}$ & $\overline{\bar{x}}$ & $\mathrm{~S}$ & $\overline{\bar{x}}$ & $\mathrm{~S}$ & & & & \\
\hline \multicolumn{11}{|l|}{ Tuhka $-A s h, \%$} \\
\hline $\mathrm{Ca} \mathrm{g} / \mathrm{kg} \mathrm{ka}-D M$ & 4.8 & 0.8 & 5.6 & 1.1 & 6.4 & 2.5 & B & A & $\mathrm{C}$ & \\
\hline $\mathrm{Mg}$ & 1.2 & 0.2 & 1.4 & 0.4 & 1.4 & 0.4 & B & $\mathrm{AC}$ & & \\
\hline $\mathbf{K}$ & 34 & 4 & 30 & 5 & 24. & 3 & & A & B & C \\
\hline $\mathbf{P}$ & 3.7 & 0.4 & 3.0 & 0.4 & 2.7 & 0.5 & B & & & $\mathrm{AC}$ \\
\hline $\mathrm{Cl}$ & 12 & 3 & 14 & 2 & 11 & 2 & $\mathrm{AC}$ & & B & \\
\hline $\mathrm{Na} \mathrm{mg/ka} \mathrm{ka}-D M$ & 161 & 62 & 153 & 61 & 150 & 41 & $\mathrm{ABC}$ & & & \\
\hline $\mathrm{Fe}$ & 269 & 148 & 195 & 99 & 420 & 506 & $\mathrm{ABC}$ & & & \\
\hline $\mathrm{Cu}$ & 17 & 7 & 18 & 7 & 16 & 8 & $\mathrm{ABC}$ & & & \\
\hline Mn & 58 & 13 & 68 & 33 & 73 & 23 & $\mathrm{AC}$ & B & & \\
\hline $\mathrm{Zn}$ & 54 & 18 & 43 & 10 & 62 & 24 & $\mathrm{AC}$ & B & & \\
\hline
\end{tabular}

1) $\mathrm{A}=1-2, \mathrm{~B}=2-3, \mathrm{C}=1-3$. 
Taulukko 2. Säilörehun kivennäiskoostumus 1., 2. ja 3. korjuukertana.

Table 2. Mineral composition of silages of 1 st, 2 nd and $3 \mathrm{rd}$ cuttings.

\begin{tabular}{|c|c|c|c|c|c|c|c|c|c|c|}
\hline & (n $=$ & $\begin{array}{l}1 \\
=39)\end{array}$ & $\left(\mathrm{n}^{2}=\right.$ & 19) & & $\begin{array}{l}3 \\
=21)\end{array}$ & Merkit & yys - & Signif & cance $^{1}$ ) \\
\hline & $\overline{\mathbf{x}}$ & S & $\overline{\mathbf{x}}$ & $\mathrm{S}$ & $\overline{\mathbf{x}}$ & $\mathrm{S}$ & NS & .05 & .01 & .001 \\
\hline $\begin{array}{l}\text { Tuhka }-A s h, \% \\
\text { of } D M \ldots \ldots \ldots \ldots . .\end{array}$ & 9.5 & 1.8 & 9.6 & 0.9 & 9.3 & 2.4 & $\mathrm{ABC}$ & & N & \\
\hline $\mathrm{Ca}$ g/ka ka $-D M$ & 4.6 & 1.0 & 5.3 & 1.0 & 5.5 & 2.0 & B & $\mathrm{AC}$ & & \\
\hline $\operatorname{Mg}$ & 1.2 & 0.3 & 1.4 & 0.4 & 1.2 & 0.3 & $\mathrm{C}$ & $\mathrm{AB}$ & & \\
\hline $\mathrm{K}$ & 31 & 7 & 27 & 5 & 19 & 4 & & A & & $\mathrm{BC}$ \\
\hline $\mathbf{P}$ & 3.4 & 0.7 & 2.9 & 0.4 & 2.5 & 0.4 & & A & B & $\mathrm{C}$ \\
\hline $\mathrm{Cl} \quad "$ & 11 & 4 & 13 & 2 & 8 & 3 & A & & C & B \\
\hline $\mathrm{Na} \mathrm{mg/kg} \mathrm{ka}-D M$ & 219 & 112 & 250 & 134 & 235 & 89 & $\mathrm{ABC}$ & & & \\
\hline $\mathrm{Fe}$ & 387 & 236 & 333 & 230 & 616 & 595 & $\mathrm{AB}$ & C & & \\
\hline $\mathrm{Cu}$ & 16 & 5 & 14 & 5 & 18 & 8 & $\mathrm{ABC}$ & & & \\
\hline $\mathrm{Mn}$ & 54 & 17 & 64 & 24 & 66 & 17 & $\mathrm{AB}$ & C & & \\
\hline $\mathrm{Zn}$ & 54 & 19 & 39 & 14 & 52 & 15 & C & & $\mathrm{AB}$ & \\
\hline $\begin{array}{l}\text { Ruohon ka- } \% \text { - } \\
\qquad D M \% \text { of grass }\end{array}$ & 31.9 & 10.4 & 37.3 & 20.8 & 27.4 & 16.2 & $\mathrm{ABC}$ & & & \\
\hline
\end{tabular}

1) $\mathrm{A}=1-2, \mathrm{~B}=2-3, \mathrm{C}=1-3$.

Taulukko 3. Ruohon ja vastaavan säilörehun kivennäiskoostumus vuosina 1970 -1973 sekä vuosien välinen hajonta.

Table 3. Mineral composition of grass and corresponding silages in the years 1970-1973, and the variation between years.

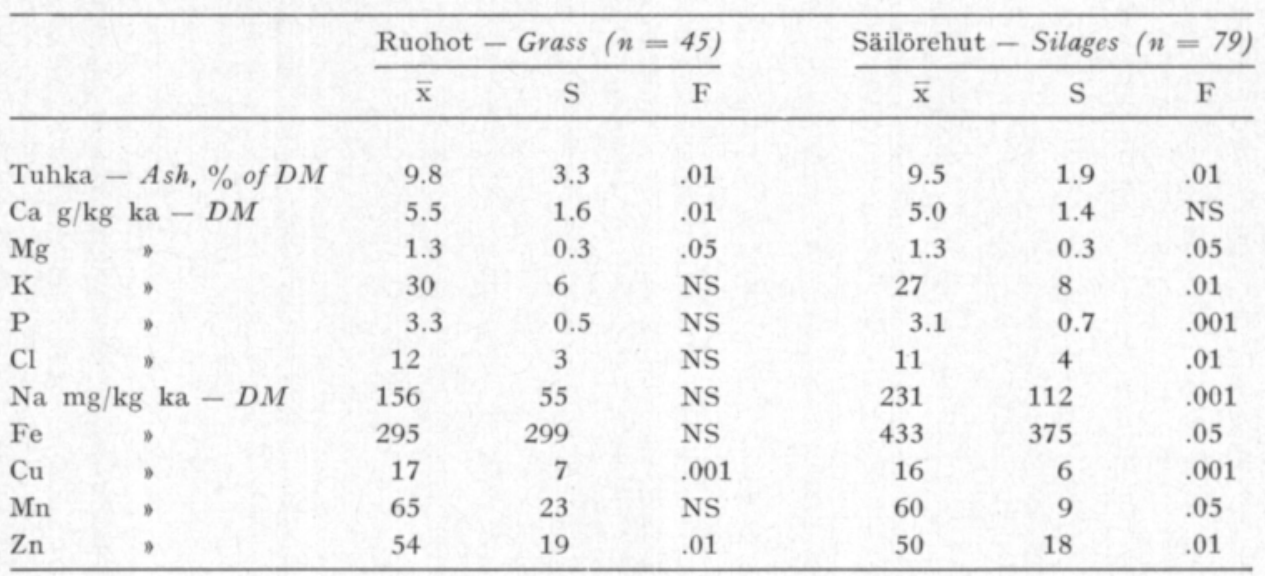

hosta vähän laskeneet, kosteimpana säilötyn kolmannen korjuukerran rehussa muita enemmän. Rauta- ja natriumpitoisuus oli noussut. Keskimääräiset muutokset säilöntäaikana käyvät ilmi taulukosta 3 .

V u o d e t. Vuosien välillä oli makrokivennäisissä jopa merkitseviä eroja $(\mathrm{P}<0.01)$ siten, että keskimäärin nuorempana korjatuissa vuosien 1970 ja 1971 ruohoissa kalsium- ja magnesiumpitoisuus oli merkitsevästi vuosien 1972 ja 1973 ruohoa korkeampi ja kaliumpitoisuus alempi. Kuparipitoisuudessa 
oli vuosien välillä suuria eroja ja syynä oli nähtävästi runsas kuparilannoitus, jota tilalla eri vuosina oli annettu eri peltolohkoille. Säilörehujen kivennäispitoisuuksiin vaikuttivat sekä raaka-aine että säilöntätappiot. Vuosien välinen hajonta muodostui sen vuoksi säilörehuissa vähän suuremmaksi kuin ruohoissa (taulukko 3).

Siil o n o s a t. Siilojen alimpaan kolmannekseen tuli $73 \%$ ensimmäisen korjuukerran rehua, mikä sisälsi keskimääräistä vähemmän kalsiumia, magnesiumia ja mangaania sekä enemmän fosforia. Samanlainen ero ilmeni myös alimman kolmanneksen säilörehussa, merkitsevyys tosin oli suurimmillaankin vain $\mathrm{P}<0.05$. Muten kivennäiskoostumus vaihteli siilojen eri osissa suhteellisen vähän.

\section{Koostumusmuutokset säilönnän aikana}

Kivennäispitoisuuksien alenemiseen säilönnän aikana vaikuttavia tekijöitä pyrittiin selvittelemään seuraavilla ryhmittelyillä:

Esikuivat u/nittotuore. Lähes kaikkien makrokivennäisten pitoisuus oli niittotuoreissa alentunut erittäin merkitsevästi enemmän kuin esikuivatuissa (taulukko 4). Hivenaineissa hajonta oli niin suuri, että vain sinkin kohdalla ero oli merkitsevä. Ero johtui selvästi niittotuoreiden suuremmasta puristemehutappiosta.

Tietyt haittatekijät. Näytteet ryhmiteltiin nyt samoin kuin kirjoituksen 1. osassa taulukossa 7 (taulukko 5). Ryhmittely osoitti jälleen, että säilörehun kivennäisarvoa alentaa nimenomaan vesi. Märkien ryhmien (1 ja 2) ja normaaliryhmien (3 ja 4) välillä oli makrokivennäispitoisuuksissa yleensä erittäin merkitsevä ero. Yläpuolelta rehuun valuva puristemehu oli pahempi vahinkotekijä kuin ruohon korjuu sateella.

Kuiva-ain etappion su uru s. Säilörehut jaettiin kuiva-ainetappion mukaan viideksi ryhmäksi, kuten kirjoituksen 1 . osan taulukossa 5 .

Taulukko 4. Koostumusmuutos säilönnän aikaan ryhmissä esikuivatut (1) ja niittotuoreet (2). Table 4. Mineral changes during ensilage in groups of wilted (1) and fresh (2) material.

\begin{tabular}{|c|c|c|c|c|c|}
\hline & $\begin{array}{c}1 \\
(\mathrm{n}=61) \\
\overline{\mathrm{x}}\end{array}$ & $\mathrm{S}$ & $\overline{\mathrm{x}}^{(\mathrm{n}}$ & 18) & $\begin{array}{c}\text { Merkitsevyys } \\
\text { Significance } \\
\text { (T-value) }\end{array}$ \\
\hline Tuhka $-A s h, \%$ units ...... & -0.1 & 1.1 & -1.0 & 1.7 & .01 \\
\hline $\mathrm{Ca}$ g/kg ka $-D M \ldots \ldots \ldots \ldots$ & -0.2 & 0.7 & -1.7 & 0.8 & .001 \\
\hline Mg $\quad, \quad, \ldots \ldots \ldots \ldots$ & +0.1 & 0.2 & -0.3 & 0.2 & .001 \\
\hline ............... & -2 & 5 & -8 & 4 & .001 \\
\hline ................ & -0.2 & 0.7 & -0.5 & 0.3 & NS \\
\hline $\mathrm{Cl} \quad, \quad \ldots \ldots \ldots \ldots$ & -1 & 4 & -4 & 2 & .001 \\
\hline $\mathrm{Na} \mathrm{mg} / \mathrm{kg} \mathrm{ka}-D M \ldots \ldots . .$. & +72 & 101 & +88 & 64 & NS \\
\hline $\mathrm{Fe} \quad, \quad \ldots \ldots \ldots$ & +104 & 118 & +75 & 410 & NS \\
\hline .......... & 0 & 3 & -2 & 5 & NS \\
\hline .......... & -3 & 15 & -9 & 15 & NS \\
\hline ........... & -1 & 14 & -14 & 25 & .01 \\
\hline $\begin{array}{l}\text { Ruohon ka- } \%- \\
D M \% \text { of grass ................ }\end{array}$ & 35.2 & 14.8 & 19.5 & 6.4 & .001 \\
\hline
\end{tabular}




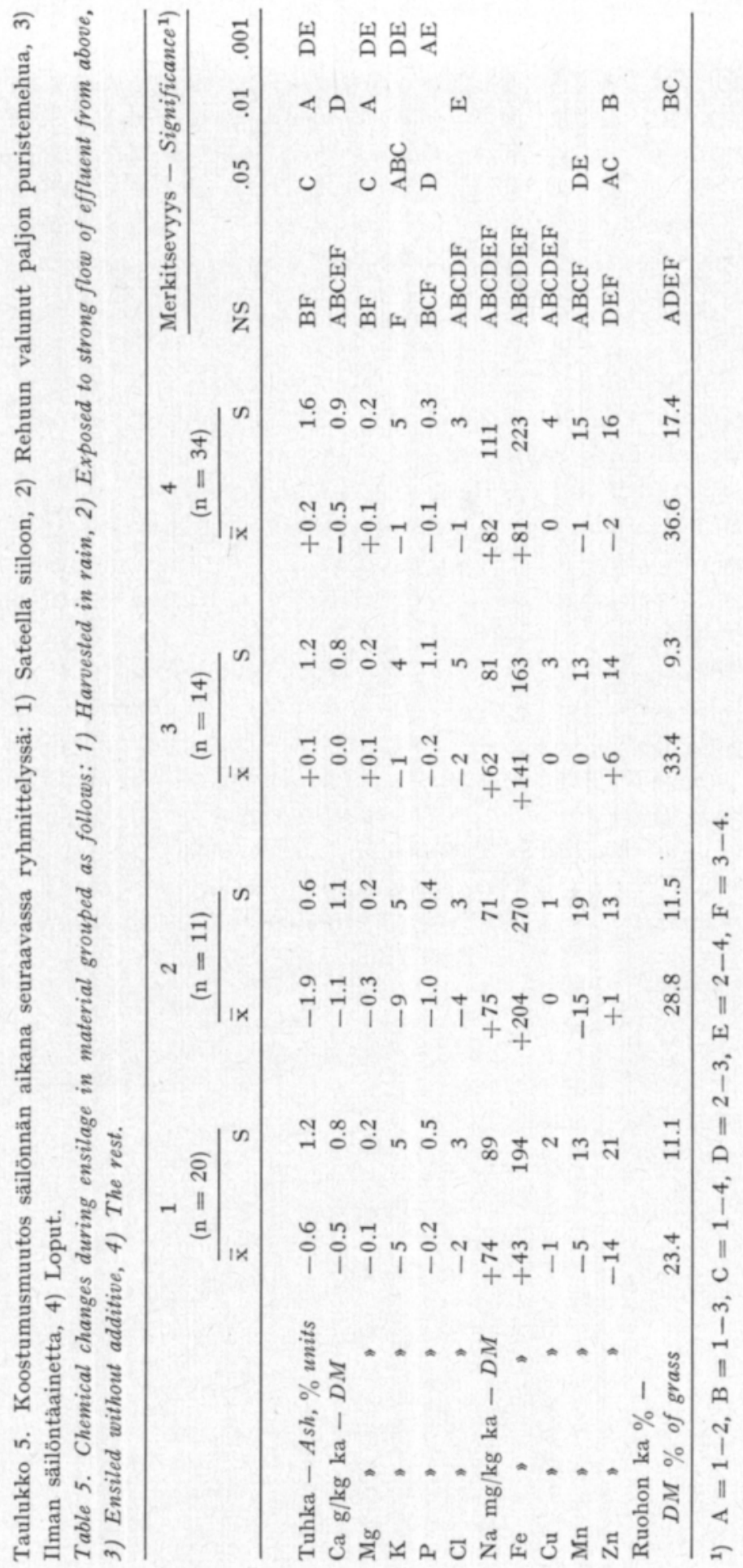


Ääriryhmät olivat yli $25 \%$ :n ja alle $5 \%$ :n kuiva-ainetappio. Kuiva-ainetappion suuruus vaikutti kivennäismuutokseen suhteellisen vähän, mikä onkin ymmärrettävää, koska tuhkatappio on vain keskimäärin $1 / 3$ kuiva-ainetappioita suurempi. Muutos pieneni suuremman tappion ryhmästä pienempään mentäessä, mutta harvoin merkitsevästi kahden ryhmän välillä. Ääriryhmien välillä ero oli suurin kaliumissa ja magnesiumissa $(\mathrm{P}<0.001)$ sekä fosforissa ja kloorissa $(\mathrm{P}<0.01)$.

\section{Kivennäistappiot}

Kivennäistappiot liittyivät kiinteästi puristemehuun. Seuraavassa ryhmittelyssä selvitellään tappioiden syitä lähemmin.

Esikuivatut/niit t ot u o r e t. Makrokivennäisten tappiot olivat niittotuoreissa yli kaksinkertaiset esikuivattuihin verrattuna $(\mathrm{P}<0.001)$ (taulukko 6). Hivenaineissa suunta oli sama, mutta suuren hajonnan vuoksi ero oli merkitsevä vain sinkin ja mangaanin kohdalla.

T i e t y t h a i t a t e kijät. Kivennäistappiot olivat märissä ryhmissä (1 ja 2) makrokivennäisten kohdalla merkitsevästi suuremmat kuin normaalirehuissa (3 ja 4). Päältä valuva runsas puristemehumäärä aiheutti suuremmat tappiot kuin korjuuajan sade. Suurimmillaan kalium-, kloori- ja fosforitappiot olivat yli $40 \%$. Hivenaineissa ryhmien välinen ero oli suuren hajonnan vuoksi jälleen epäselvempi (taulukko 7).

$\mathrm{K}$ orju u k r r a j a vu odet. Korjuukertojen välillä todetut tappioerot myötäilivät täysin ruohon kuiva-ainepitoisuutta: kuivimmassa 2 . korjuukerran ruohossa ne olivat pienimmät, märimmässä 3. korjuukerran ruohossa suurimmat. Erojen merkitsevyys oli makrokivennäisissä $\mathrm{P}<0.05-0.001$ luokkaa.

Vuosien väliset erot johtuivat niinikään ruohon erilaisesta vesipitoisuudesta: tappiot olivat suurimmat vuonna 1970 , jolloin ruoho ajettiin siiloon kosteimpana ja pienimmät vuonna 1973, jolloin se oli kuivinta. Esimerkkinä eroista mainittakoon, että vuonna 1970 sekä kalsiumin että fosforin tappio oli $25 \%$ ja vuonna 197311 ja $10 \%$. Vuodet 1971 ja 1972 sijoittuivat tälle välille.

Taulukko 6. Säilöntätappiot (\% ryhmissä esikuivatut (1) ja niittotuoreet (2).

Table 6. Preservation losses (\%) in groups of wilted (1) and fresh (2) material.

\begin{tabular}{|c|c|c|c|c|c|}
\hline & \multicolumn{2}{|c|}{$\begin{array}{c}1 \\
(\mathrm{n}=61)\end{array}$} & \multicolumn{2}{|c|}{$\begin{array}{c}2 \\
(\mathrm{n}=18)\end{array}$} & \multirow{2}{*}{$\begin{array}{c}\text { Merkitsevyys } \\
\text { Significance } \\
\text { (T-value) }\end{array}$} \\
\hline & $\overline{\mathbf{x}}$ & $\mathrm{S}$ & $\overline{\mathbf{x}}$ & $\mathrm{S}$ & \\
\hline Tuhka - Ash ...................... & 13.3 & 12.1 & 25.4 & 13.3 & .001 \\
\hline $\mathrm{Ca}$ & 14.6 & 11.8 & 37.6 & 13.4 & .001 \\
\hline 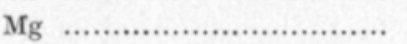 & 16.7 & 12.3 & 35.7 & 13.8 & .001 \\
\hline K & 18.7 & 16.3 & 38.5 & 17.4 & .001 \\
\hline 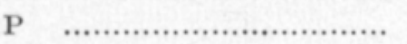 & 15.1 & 16.5 & 29.9 & 12.9 & .001 \\
\hline - & 17.7 & 17.0 & 44.9 & 14.4 & .001 \\
\hline Na & +57 & 52 & +38 & 27 & NS \\
\hline Fe & +38 & 52 & +58 & 47 & NS \\
\hline Cu & 18.4 & 13.5 & 24.5 & 17.7 & NS \\
\hline Mn & 18.3 & 16.8 & 29.5 & 14.3 & .05 \\
\hline Zn & 20.4 & 17.0 & 32.4 & 22.2 & .05 \\
\hline
\end{tabular}


Taulukko 7. Säilöntätappiot (\%) seuraavassa ryhmittelyssä: 1) Sateella siiloon, 2) Rehuun valunut paljon puristemehua, 3) Ilman säilöntäainetta, 4) Loput.

Table 7. Preservation losses (\%) in material grouped as follows: 1) Harvested in rain, 2) Exposed to strong flow of effluent from above, 3) Ensiled without additive, 4) The rest.

\begin{tabular}{|c|c|c|c|c|c|c|c|c|c|c|c|c|c|}
\hline & \multirow{2}{*}{\multicolumn{2}{|c|}{$\begin{array}{c}1 \\
(\mathrm{n}=20) \\
\end{array}$}} & \multirow{2}{*}{\multicolumn{2}{|c|}{$\begin{array}{c}2 \\
(\mathrm{n}=11) \\
\end{array}$}} & \multirow{2}{*}{\multicolumn{2}{|c|}{$\begin{array}{c}3 \\
(n=14)\end{array}$}} & \multirow{2}{*}{\multicolumn{2}{|c|}{$\begin{array}{c}4 \\
(n=34)\end{array}$}} & \multicolumn{4}{|c|}{ Merkitsevyys - Significance ${ }^{1}$} \\
\hline & & & & & & & & & & \multirow[b]{2}{*}{ NS } & \multirow[b]{2}{*}{.05} & \multirow[b]{2}{*}{.01} & \multirow[b]{2}{*}{.001} \\
\hline & & $\overline{\mathbf{x}}$ & $\mathrm{S}$ & $\bar{x}$ & $\mathrm{~S}$ & $\bar{x}$ & $\mathrm{~S}$ & $\overline{\mathbf{x}}$ & $\mathbf{S}$ & & & & \\
\hline \multicolumn{2}{|c|}{ Tuhka $-A s h$} & 18.7 & 13.5 & 35.0 & 9.9 & 11.5 & 9.5 & 11.3 & 10.3 & $\mathrm{BF}$ & C & \multirow[t]{2}{*}{ A } & DE \\
\hline $\mathrm{Ca}$ & ................ & 24.4 & 16.2 & 33.5 & 15.6 & 12.2 & 11.2 & 14.5 & 12.1 & $\mathrm{AF}$ & $\mathrm{BC}$ & & DE \\
\hline $\mathrm{Mg}$ & ................ & 21.2 & 17.4 & 36.5 & 12.2 & 18.0 & 7.5 & 16.0 & 12.5 & BCF & A & & DE \\
\hline K & ................ & 29.1 & 18.6 & 43.9 & 19.9 & 13.5 & 10.2 & 16.4 & 13.6 & F & A & $\mathrm{BC}$ & DE \\
\hline $\mathbf{P}$ & ................. & 23.5 & 16.2 & 41.1 & 11.9 & 11.6 & 15.1 & 10.5 & 10.6 & F & B & A & $\mathrm{CDE}$ \\
\hline $\mathrm{Cl}$ & ............... & 26.7 & 17.1 & 47.3 & 20.8 & 18.5 & 12.3 & 17.1 & 18.6 & BCF & & A & DE \\
\hline $\mathrm{Na}$ & ................. & +49 & 48 & +44 & 32 & +39 & 37 & +63 & 56 & ABCDEF & & & \\
\hline $\mathrm{Fe}$ & ................ & +48 & 46 & +43 & 52 & +25 & 25 & +46 & 62 & ABCDEF & & & \\
\hline $\mathrm{Cu}$ & ................. & 25.9 & 13.3 & 15.2 & 8.4 & 17.7 & 15.1 & 16.3 & 15.0 & ABDEF & $\mathrm{C}$ & & \\
\hline Mn & ............... & 27.5 & 14.3 & 30.6 & 19.0 & 15.2 & 18.6 & 15.7 & 14.5 & ADF & BE & C & \\
\hline $\mathrm{Zn}$ & ................ & 34.3 & 25.4 & 17.2 & 13.1 & 22.8 & 15.7 & 17.8 & 13.0 & BDEF & A & C & \\
\hline
\end{tabular}

1) $\mathrm{A}=1-2, \mathrm{~B}=1-3, \mathrm{C}=1-4, \mathrm{D}=2-3, \mathrm{E}=2-4, \mathrm{~F}=3-4$.

\section{Korrelaatiot}

Kivennäisten riippuvuutta toisistaan ja muista aineista sekä tappioiden välisiä suhteita selviteltiin laskemalla korrelaatiokertoimia.

Ruohossa todettiin korrelaatio fosforin ja kaliumin ja kalsiumin ja magnesiumin välillä (taulukko 8). Edelleen kävi ilmi, että runsaasti proteiinia sisältävä ruoho sisältää paljon fosforia ja kaliumia, ja raakakuitu vuorostaan korreloituu negatiivisesti kalsiumiin ja magnesiumiin. Makrokivennäistappiot korreloituivat kiinteästi toisiinsa ja monien orgaanisten aineiden tappioihin (taulukko 9). Vahvin korrelaatio kivennäistappioiden ja ruohon vesipitoisuuden välillä todettiin sateella siiloon ajettujen ryhmässä ja siilojen ylimmässä kolmanneksessa.

Taulukko 8. Korrelaatiokertoimet ruohon kivennäis- ja muiden pitoisuuksien ( $\%$ ka:sta) välillä $(\mathrm{n}=45)$ Table 8. Correlation coefficients between the mineral and other components ( $\%$ of DM) of grass $(n=45)$.

\begin{tabular}{|c|c|c|c|c|c|c|c|c|c|c|c|}
\hline \multirow{2}{*}{ 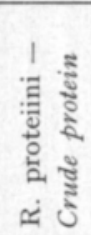 } & \multirow{2}{*}{ 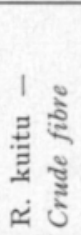 } & \multirow{2}{*}{$\begin{array}{l}\text { के } \\
1 \\
1 \\
\frac{5}{3} \\
\text { है }\end{array}$} & \multirow{2}{*}{ 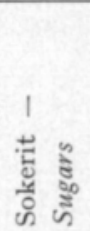 } & \multirow[t]{2}{*}{ 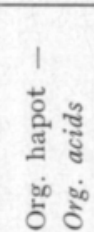 } & \multirow{2}{*}{ 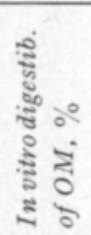 } & \multirow[t]{2}{*}{ 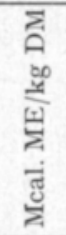 } & $\mathrm{Ca}$ & $\mathrm{Mg}$ & $\mathbf{K}$ & $\mathrm{P}$ & \multirow[t]{2}{*}{$\mathrm{Cl}$} \\
\hline & & & & & & & & $\mathrm{g} / \mathrm{k}$ & ka & DM & \\
\hline
\end{tabular}

\begin{tabular}{llllllllllllll}
$\mathrm{Ca} g / \mathrm{kg}$ & $\mathrm{ka}-D M$ & .14 & $-.49^{3}$ & .21 & .09 & $.43^{2}$ & .19 & .18 & 1.00 & & & & \\
$\mathrm{Mg}$ & .13 & $-.31^{1}$ & $.30^{1}$ & -.10 & $.32^{1}$ & .08 & .15 & $.74^{3}$ & 1.00 & & & \\
$\mathrm{~K}$ & & $.48^{3}$ & .09 & .27 & $-.40^{2}$ & .03 & .20 & $.34^{1}$ & $-.33^{1}$ & -.15 & 1.00 & & \\
$\mathrm{P}$ & & $.42^{2}$ & .12 & .24 & $-.35^{1}$ & .05 & .28 & $.37^{2}$ & $-.38^{2}$ & -.14 & $75^{3}$ & 1.00 & \\
$\mathrm{Cl}$ & & .20 & .20 & $.29^{1}$ & $-.34^{1}$ & -.26 & -.21 & -.02 & $-.30^{1}$ & .12 & $.51^{3}$ & $44^{2}$ & 1.00 \\
\hline
\end{tabular}

$1=\mathrm{P}<0.05,2=\mathrm{P}<0.01,3=\mathrm{P}<0.001$. 
Taulukko 9. Tappioiden (\%) riippuvuus ruohon kuiva-ainepitoisuudesta ja toisistaan.

Table 9. Correlation coefficients between the various losses (\%) and the DM \% grass.

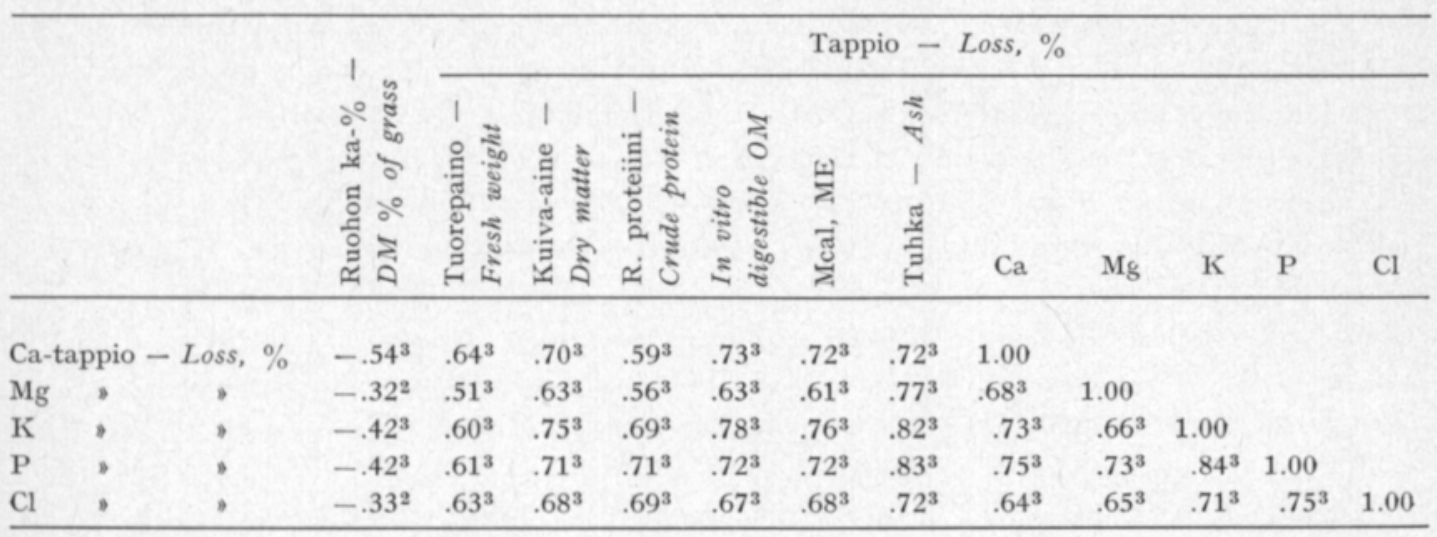

$1=\mathrm{P}<0.05,2=\mathrm{P}<0.01,3=\mathrm{P}<0.001$.

\section{Tulosten tarkastelu}

Nurmikasvien kivennäispitoisuuteen vaikuttaa mm. kasvilaji, kasvuaste (Mäkelä 1967, Raininko 1968), maalaji ja lannoitus (LAKAnen 1969, Rinne 1973), Säilörehun raaka-aineen kivennäiskoostumuksessa esiintyy sen vuoksi samallakin tilalla eroja eri vuosina ja eri korjuukerroilla. Se kävi ilmi myös tässä tutkimuksessa. Todetut ruohon kalsium-, fosfori- ja kaliumpitoisuudet olivat Kossilan ym. (1973) havaitsemissa rajoissa, magnesium- ja natriumpitoisuudet olivat niitä alempia ja samaa luokkaa, mitä RAInınko (1968) on vuonna 1967 todennut Viikin koetilan säilörehuasteisesta ruohosta. Mikrokivennäisistä kupari- ja suureksi osaksi myös sinkkipitoisuus olivat mainittujen tutkijain havaintoja korkeammat, mangaanipitoisuus vuorostaan samaa tasoa tai alempi. Viikin kasvinäytteiden korkea ja epätasainen kuparipitoisuus - mikä pantiin merkille myös sokerijuurikkaan naateissa (SALO ym. 1974) - johtunee pelloille viime vuosina annetusta runsaasta kuparilannoituksesta. Rautapitoisuus vaihteli paljon ja syyksi havaittiin jo aiemmin (SALo ym. 1972) sade: se lisää ruohon multaantumista ja mullan rauta liukenee kivennäisainemäärityksissä. Rauta korreloikin kiinteästi tuhkapitoisuuteen $\left(\mathrm{r}=.73^{* * *}\right)$. Saattaa olla, että multa nostaa pienessä määrin myös sinkki- ja natriumpitoisuutta, koska näiden ja raudan välillä ilmeni kiinteä positiivinen korrelaatio $(\mathrm{Zn}: \mathrm{r}=. \mathbf{5 7}$,*** $\left.\mathrm{Na}: \mathrm{r}=.46^{* * *}\right)$.

Ruohon kalsium-, magnesium- ja mangaanipitoisuudet nousivat ensimmäisestä kolmanteen korjuukertaan, fosfori- ja kaliumpitoisuudet vuorostaan laskivat. Vastaavanlaisia korjuukertamuutoksia ovat todenneet MüLLER ym. (1971) ja Rinne (1973). Kolmannen korjuukerran ruohon korkea kalsiumpitoisuus johtui osaksi siitä, että osa odelmanäytteistä sisälsi apilaa.

Säilönnän aikana ruohon kivennäisiä huuhtoutuu puristemehussa. Esikuivattujen ja niittotuoreiden välillä olikin suuri ero makrokivennäisten sekä tappioissa että pitoisuuksien alenemisessa $(\mathrm{P}<0.001)$. Vielä selvemmin huuhtoutumisen vaikutus kävi ilmi ryhmittelyssä, missä sateella korjatut ja 
runsaan puristemehun huuhtomat koottiin omiksi ryhmikseen. Esim. fosforitappiot, mitkä »normaaliryhmissä» olivat noin $10 \%$, nousivat sateella korjatuissa yli kaksinkertaisiksi ja puristemehun huuhtomissa yli nelinkertaisiksi. Toisaalta mikään ei viitannut siihen, että huuhtoutuneita kivennäisiä olisi pidättynyt alempiin säilöntäkerroksiin: kivennäismuutokset ja -tappiot siilon eri osissa olivat samaa luokkaa. Hivenaineissa ilmeni suurta vaihtelua, minkä seikan ovat todenneet myös LAKANEN (1969) ja Kossila ym. (1973). Yhtäpitävä Kossilan tulosten kanssa on myös havainto, että säilörehussa on rautaa ja natriumia enemmän kuin raaka-aineessa. Selitys tähän lienee analyysitekniikassa. Esikuivatuksen kivennäistappioita vähentävä vaikutus on todettu muissakin tutkimuksissa (WATSON ja NASH 1960). Myös niittotuoretta ruohoa säilöttäessä korkea kuiva-ainepitoisuus on havaittu edulliseksi (KossıLA ym. 1973).

Koska tuhkatappiot olivat keskimäärin noin kolmanneksen suurempia kuin kuiva-ainetappiot, laskivat ruohon kivennäispitoisuudet säilönnän aikana. Aleneminen oli $0-10 \%$ :n luokkaa ja niittotuoreissa suurempi kuin esikuivatuissa $(\mathrm{P}<0.001)$. Tulos on yhtäpitävä Kossıllan ym (1973) niittotuoreista säilörehuista tekemien havaintojen kanssa.

Esitetty koe antoi selvän kuvan siitä, että ruohoa esikuivaamalla vähennetään ratkaisevasti kivennäistappioita. Korkeissa siiloissa - nimenomaan niiden alaosissa - tappioita todettiin vielä lähelle $30 \%$ :n kuiva-ainepitoisuutta kuivatussa ruohossa. $30 \%$ ka pidetäänkin rajana, missä puristemehun muodostuminen lakkaa (Gross ja RIEBE 1974). Rehun kivennäisarvolle tappioiden väheneminen merkinnee enemmän mitä tappioprosentit osoittavat, koska eläimet todennäköisesti pystyvät käyttämään hyväkseen vesiliukoisia kivennäisiä keskimääräistä paremmin. Esikuivaamalla ruohoa vältytään myös puristemehun talteenottoon tarvittavilta toimenpiteiltä. (Vesistöön laskettuna puristemehu on eräs pahimpia ympäristösaasteita.)

\section{Yhteenveto}

Tutkimus käsittelee nurmisäilörehussa käytännön oloissa vuosina 19701973 todettuja kivennäispitoisuuksien muutoksia ja kivennäistappioita. Rehu tehtiin $9 \mathrm{~m}$ korkeisiin tornisiiloihin ja samaan siiloon pantiin usein sekä esikuivattua että niittotuoretta tai sateen kastelemaa ruohoa. Tutkimus suoritettiin siiloihin pantujen koesäkkien avulla. Aineisto oli sama kuin kirjoituksen osassa 1. Kivennäismääritykset tehtiin 45 ruohonäytteestä ja 79 säilörehunäytteistä, joista 61 oli esikuivattuja (osa sateen kastelemia) ja 18 niittotuoretta.

Ruohon P- ja K-pitoisuus laski $(\mathrm{P}<0.001)$ ja $\mathrm{Mg}$ - ja $\mathrm{Ca}$-pitoisuus nousi $(\mathrm{P}<0.05-0.01)$ ensimmäisestä kolmanteen korjuukertaan mennessä. Sama ero näkyi vastaavissa säilörehuissa.

Makrokivennäisten $(\mathrm{Ca}, \mathrm{Mg}, \mathrm{K}, \mathrm{P}, \mathrm{Cl})$ säilöntätappio oli esikuivatuissa pienempi kuin niittotuoreissä $(\mathrm{P}<0.001)$. Suurin tappio todettiin näytteissä, joihin päältä oli valunut runsaasti puristemehua. Korjuu sateella oli toinen paha tappioiden aiheuttaja.

Tuhkatappio oli noin $1 / 3$ suurempi kuin ka-tappio ja säilörehun kivennäispitoisuudet olivat sen vuoksi $0-10 \%$ raaka-aineen pitoisuuksia alemmat. 
Useimpien makrokivennäisten pitoisuuksien lasku oli esikuivatuissa merkitsevästi pienempi kuin niittotuoreissa $(\mathrm{P}<0.001)$. Hivenaineissa ilmeni hajontaa, mutta keskimäärin $\mathrm{Mn}$-, $\mathrm{Zn}$ - ja Cu-pitoisuudet olivat vain vähän alempia kuin raaka-aineessa. Ruohon multaantuminen nosti Fe-pitoisuuden korkeaksi.

Ruohossa todettiin kiinteä korrelaatio seuraavien pitoisuuksien välillä: $\mathrm{Ca} / \mathrm{Mg}, \mathrm{P} / \mathrm{K}, \mathrm{K} / \mathrm{Cl}, \mathrm{Fe} / \mathrm{Na}, \mathrm{Fe} / \mathrm{Zn}(\mathrm{P}<0.001)$. Myös kivennäisten ja eräiden orgaanisten aineiden välillä ilmeni kiinteitä korrelaatioita. Kivennäistappioiden riippuvuus ruohon ka-pitoisuudesta oli selvin sateella korjatuissa ja siilojen ylimpään kolmannekseen säilötyissä näytteissä.

\section{KIRJALLISUUTTA}

Gross, F. \& RiEbe, K. 1974. Gärfutter 283 p. Stuttgart.

Kossila, V., Ettala, E., Virtanen, E. \& Kommeri, M. 1973. Säilörehujen kivennäis- ja hivenainepitoisuuksista. Karjatalous 8/1973:16-19.

Lakanen, E. 1969. Mineral composition of Finnish timothy. Ann. Agric. Fenn. 8:20-29.

MÜLler, H. L., Voigtränder, G. \& Kirchgessner, M. 1971. Veränderungen des Gehaltes an Mengenelementen $(\mathrm{Ca}, \mathrm{Mg}, \mathrm{P}, \mathrm{Na}, \mathrm{K})$ von Weidegras in Abhängigkeit von Wachstumsdauer und Vegetationsperiode. Wirtschaftseigene Futter 17: 165-178.

MäKelä, A. 1967. On the water-solubility of plant minerals. J. Sci. Agric. Soc. Finl. 39: $166-182$.

Poutiainen, E. \& RiNNE, K. 1971. Korjuuasteen vaikutus säilörehun ravintoarvoon. Kehittyvä maatalous $3: 15-28$.

RaININKo, K. 1968. The effects of nitrogen fertilization, irrigation and number of harvestings upon leyes established with various seed mixtures. Suom. Maatal.tiet. Seur. Julk. 112: $1-137$.

RINNE, S.-L. 1973. Runsaan typpilannoituksen vaikutus säilörehusteella olevan nurminadan ja koiranheiriän kivennäisainepitoisuuteen. Koetoim. ja Käyt. 30:30-31.

SALO, M.-L. \& Sormunen, R. 1974. Sokerijuurikkaan naatit ja niistä valmistettu säilörehu. Maatal.tiet.aikak. 46: 88-96, 97-102.

- - - SUOMI, K. \& Sormunen, R. 1972. Esikuivatuissa ja niittotuoressa säilörehussa tapahtuvat ravinnetappiot. Koetoim. ja Käyt. 29:18-19.

TAUSSKY, H. H. \& SHORR, E. 1953. A microcolorimetric method for the determination of inorganic phosphorus. J. Biol. Chem. 202: 675-685.

WAtson, S. J. \& NASH, M. J. 1960. The conservation of grass and forage crops. 758 p. Edinburgh. 